\title{
UPAYA PENCAPAIAN DANA DALAM MENINGKATKAN MUTU SEKOLAH DENGAN PROSES TOTAL QUALITY MANAGEMENT (TQM)
}

\author{
Fadhilaturrahmah' Achmad Supriyanto ${ }^{2}$ Agus Timan $^{3}$ \\ Universitas Negeri Malang, Jl Semarang No.5 Malang \\ e-mail: dhilaturrahmah@gmail.com
}

\begin{abstract}
A way to improve school quality in fulfilling funds requires the adoption of an approach with TQM. The principles of financial management in education include: (I) justice; (2) efficiency; (3) effective; (4) transparency; and (5) Accountable. The research conducted is qualitative research. MTs Sunan Kalijogo found several problems in the spotlight, namely the unfavorable funding standards at Sunan Kalijogo MTs. Implementing Total Quality Management (TQM) with the concepts of Plan, Do, Check, and Act (PDCA) MTs Sunan Kalijogo indirectly implemented, but in its implementation has not shown significant success. Funding problems are a problem in improving the quality of MTs Sunan Kalijogo after being re-evaluated using funds to meet school needs appropriately, when balanced with the concepts of Plan, Do, Check and Act
\end{abstract}

Keywords: Achievement of Funds, TQM, PDCA.

Abstrak: Cara untuk memperbaiki mutu sekolah dalam pemenuhan dana maka dibutuhkan adanya penerapan sebuah pendekatan dengan TQM. Prinsip manajemen keuangan dalam pendidikan diantaranya: (I) keadilan; (2) efisiensi; (3) efektif; (4) transparansi; dan (5) Akuntabel. Penelitian yang dilakukan merupakan penelitian kualitatif. MTs Sunan Kalijogo ditemukan beberapa permasalahan yang menjadi sorotan yaitu belum baiknya standar pembiayaan di MTs Sunan Kalijogo. Pengimplementasian Total Quality Management (TQM) dengan konsep Plan, Do, Check, and Act (PDCA) MTs Sunan Kalijogo secara tidak langsung sudah dilaksanakan, tetapi dalam pelaksanaanya belum menunjukan keberhasilan yang signifikan. Permasalahan dana yang menjadi masalah dalam meningkatkan mutu MTs Sunan Kalijogo setelah di evaluasi kembali penggunaan dana untuk memenuhi kebutuhan sekolah dengan tepat, bila diseimbangkan dengan konsep Plan, Do, Check and Act.

Kata Kunci: Pencapaian Dana, TQM, PDCA.

\section{PENDAHULUAN}

Peraturan Pemerintah Republik Indonesia Nomor 48 Tahun 2008 tentang Pendanaan Pendidikan pasal I ayat 3 dinyatakan bahwa dana pendidikan adalah sumber daya keuangan yang disediakan untuk menyelenggarakan dan mengelola pendidikan. Dalam peraturan tersebut dijelaskan bahwa pendidikan juga di atur pendanaannya dalam tercapainya keberhasilan serta tujuan dari pendidikan.

Sama halnya dengan peraturan di atas, Peraturan Pemerintah Republik Indonesia Nomor 48 Tahun 2008 tentang Pendanaan Pendidikan pasal 2 ayat I menyatakan bahwa dalam pendanaan pendidikan menjadi tanggung jawab bersama antara pemerintah, pemerintah daerah, dan masyarakat. Yang dimaksud dari pasal tersebut yaitu keuangan ataupun dana yang diperoleh dalam pengelolaan di Indonesia bersumber dari ke tiga peranan tersebut, sehingga dari peranan penting tersebut akan menghasilkan dana yang mencukupi untuk memenuhi fasilitas dari pendidikan itu sendiri.

Dari peraturan pemerintah di atas, dapat diketahui bahwa dana untuk pendidikan di Indonesia telah diatur dengan kebijakan yang berlaku, sehingga memiliki arah dan tujuan yang jelas dalam pencapaiannya yaitu untuk pendidikan di Indonesia. 
Nur dkk (2016) menyatakan rentetan perubahan peristiwa dalam mengatur ketika melaksanakan fungsi dari pendidikan dengan cara memanfaatkan semua sumber seefesien mungkin dalam menggapai arah dengan keefektifan yaitu manajemen pendidikan proses manajemen dalam pelaksanaan tugas pendidikan dengan mendayagunakan segala sumber secara efesien untuk mencapai tujuan secara efektif. Peraturan atau pengaturan sekolah mempunyai maksud pengoptimalan segala sesuatu untuk mengola termasuk didalamnya pengoptimalkan keuangan pendidikan. Mengoptimakan sumber daya berkaitan dengan keuangan pendidikan ini yang merupakan cara yang sekiranya tepat untuk mewujudkan tujuan terpenuhinya kebutuhan pendidikan, termasuk lembaga pendidikan baik itu di sekolah negeri ataupun sekolah swasta.

Mulyono (2015) dalam Widyatmoko dan Suyatmin (2017) mengemukakan dana Bantuan Operasional Sekolah merupakan sebuah rancangan dari pemerintah dalam hal membantu menyediakan dana pembiayaan secara tidak personalia dari lembaga pendidikan. Rancangan BOS diketuai Kementeriandikbud, dimana terlaksananya, proses serta kelola pendanaan BOS memiliki pedoman yang harus dilakukan yang ada di buku pegangan pemakaian pendanaan BOS yang diluncurkan oleh Kementerian Pendidikan dan Kebudayaan dan Kementerian Agama sebagai kementerian teknis dalam pertanggungjawaban untuk melaksanakan serta mengelola rancangan BOS.

Pada kenyataanya di sekolah walaupun memiliki dana bantuan BOS namun faktanya ada permasalahan kekurangan dana yang dihadapi, sehingga upaya peningkatan kualitas pendidikan dan sekolah menjadi kurang terpenuhi dengan baik dan yang seharusnya. Sehubungan dengan upaya peningkatan kualitas dari sekolah dalam pemenuhan dana maka dibutuhkan adanya penerapan sebuah pendekatan Manajemen Mutu Terpadu atau juga dikatakan Total Quality Management dan disingkat TQM. TQM memiliki beberapa aspek pendukung untuk meningkatkan kualitas pendidikan dan sekolah secara maksimal.

\section{Prinsip Manajemen Keuangan Pendidikan}

Alkurnia dan Anggriani (2017) mengemukakan ada beberapa prinsip yang yang menjadi landasan dari keuangan pedidikan dimana prinsip-prinsip tersebut yang menjadi patokan dalam mengelola keuangan yang dapat menjadi acuan, prinsip-prinsip tersebut diantaranya:

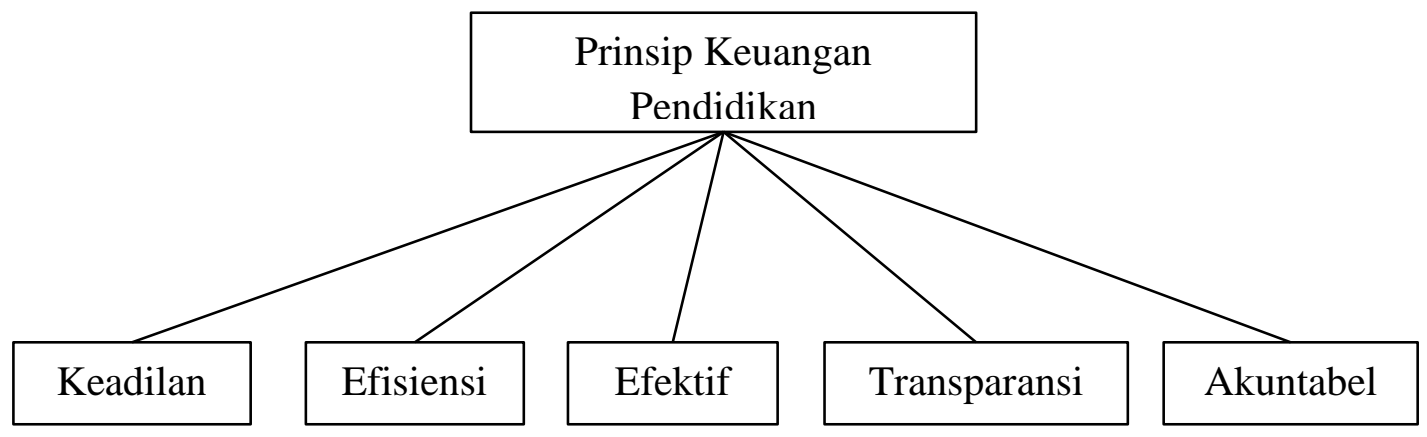

\section{Bagan I. Prinsip Keuangan Pendidikan}

I. Keadilan

Alkurnia dan Anggriani (2017) juga menyatakan dalam pemerataan pendidikan yang memiliki prinsip keadilan maka sekolah di wajibkan untuk mengelola keuangan dari dana BOS dari pemerintah kepada seluruh sekolah negeri maupun sekolah swasta dilakukan secara adil yang berkaitan dengan kebijakan serta aturan yang sesuai dengan kondisi sekolah.

2. Efisiensi

Peraturan Pemerintah Republik Indonesia Nomor 48 Tahun 2008 menyatakan bahwa efisiensi dalam pengelolaan dana pendidikan dilakukan dengan mengoptimalkan akses, mutu, relevansi, dan daya saing pelayanan pendidikan. Masditou (2017) mengemukakan 
beberapa aspek yang dilihat dalam efesiensi yaitu dalam menggunakan penggunaan time, ketenagaan, dan dana, kemudian hasil kegiatan dapat dinyatakan berjalan baik jika baik kuantitas maupun kualitasnya.

3. Efektif

Alkurnia dan Anggriani (2017) mengemukakan bahwa efektifitas memiliki hubungan dengan sudah terlaksanakannya semua bentuk tugas pokok, pencapaian dalam sebuah tujuan, tepatnya waktu dan ada partisipasi yang aktif.

4. Transparansi

Sumber keuangan yang di peroleh oleh sekolah terdiri dari berapa jumlah keuangan, berapa besar rincian penggunaan yang dilakukan secara jelas untuk mengetahui seberapa besar keuangan yang keluar serta masuk.

5. Akuntabel

Tiga aspek yang menjadi landasan dari akuntabilitas menurut Alkaz (20I3) diantaranya:

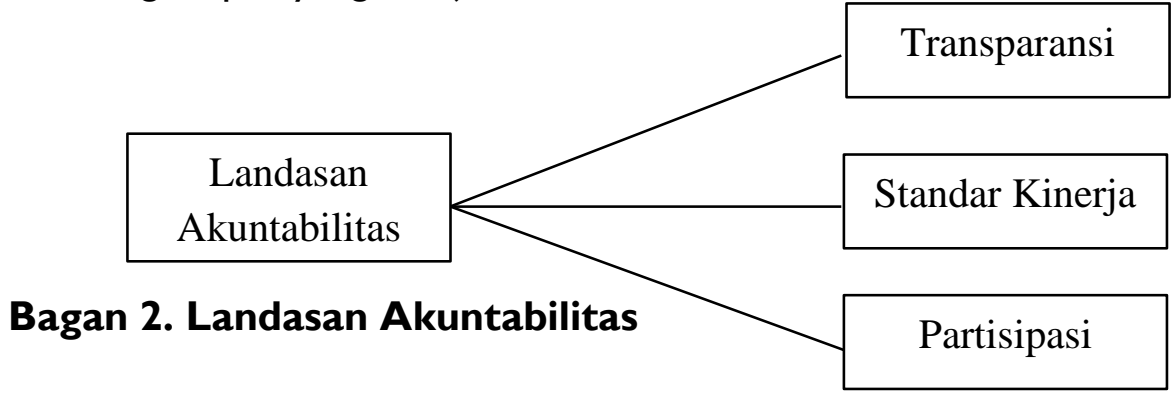

\section{METODOLOGI}

Penelitian yang dilakukan merupakan penelitian kualitatif, dimana yang menjadi metode dasar yang digunakan oleh peneliti adalah pengamatan yang dilakukan di lapangan dan dokumentasi. Studi kasus yang dilakukan dengan mengumpulkan data melalui observasi atau studi lapang kemudian dokumentasi dari lembar EDS MTs Sunan Kalijogo Malang.

Observasi dilakukan dengan melakukan pengamatan disekolah untuk untuk menyingkronkan data. Setelah itu dokumentasi dimana dokumentasi dilakukan dengan melihat lembar Evaluasi Diri Sekolah (EDS) MTs Sunan Kadijigo yang diberikan oleh pihak sekolah, kemudian peneliti melihat lembar EDS tersebut dan melihat permasalahan yang terjadi apa saja, sehingga dapat diketahui dari berbagai permasalahan yang ada.

\section{HASIL DAN PEMBAHASAN}

\section{Hasil}

Setelah dilakukannya observasi dengan pengamatan di lapangan dan dokumentasi di MTs Sunan Kalijogo ditemukan beberapa permasalahan yang menjadi sorotan diantaranya:

- Kurang adanya partisipasi stakeholders (komite sekolah/madrasah, penyelenggara pendidikan, dsb) dalam mengembangkan kurikulum sekolah;

- Sebagian besar siswa belum mempunyai keahlian untuk melakukan sendiri, dengan orang lain serta dan komunikasi untuk mengembangkan atas apa yang telah dipelajari;

- Belum tersedianya tenaga administrasi, pustakawan, dan laboran yang sesuai kualifikasi;

- Kelengkapan sarana dan prasarana masih kurang dan kondisinya belum sesuai standar; dan

- Standar pembiayaan perlu mendapatkan perhatian.

Dari permasalahan yang dijabarkan di atas, peneliti menyorot permasalahan bagian terakhir dimana belum baiknya standar pembiayaan di MTs Sunan Kalijogo yang merupakan aspek 
penting dalam meningkatkan mutu sekolah. Ada beberapa aspek dari standar pembiyaan yang perlu mendapatkan perhatian secara garis besar diantaranya:

- Madrasah perlu adanya Rencana Kerja dan Anggaran selama 3 tahun terakhir.

- Madrasah perlu membuat dokumen investasi sarpras yang lebih tidak ada kurangnya, dan perlu pembelanjaan biaya untuk pengembangan guru yang ada pada RKA selama 3 tahun terakhir.

- Madrasah perlu belanja dan melapor untuk 3 tahun terakhir.

- Pengelolaan dana dari pemerintah maupun masyarakat dalam 3 tahun terakhir perlu meningkatkan pengelolaan secara baik.

\section{Pembahasan}

Sutarto (2015) mengemukakan monitoring dan evaluasi dalam melaksanakan program sesuai dengan prinsip PDCA dari Deming. Terlaksananya PDCA harus terus menerus. Pengimplementasian Total Quality Management (TQM) dengan konsep Plan, Do, Check, and Act (PDCA) Mts Sunan Kalijogo secara tidak langsung sudah dilaksanakan, akan tetapi dalam pelaksanaanya dirasa belum tepat dan belum menunjukan keberhasilan yang signifikan, hal ini dikarenakan munculnya berbagai permasalahan yang terjadi setelah di analisis dari Evaluasi Diri Sekolah Mts Sunan Kalijogo. Permasalahan dana yang menjadi masalah penting disini karena dana adalah sumber untuk meningkatkan mutu sekolah, permasalahan belum baiknya standar pembiayaan di MTs Sunan Kalijogo perlu dilakukan PDCA kembali.

Plan, Do, Check, and Act (PDCA) merupakan sebuah cara dalam dalam TQM untuk dapat memberi kemungkinan sebuah lembaga atau sekolah mengadakan perubahan untuk alur serta cara secara berkelanjutan dan dilakukan evaluasi pada diri sekolah (MTs Sunan Kalijogo).

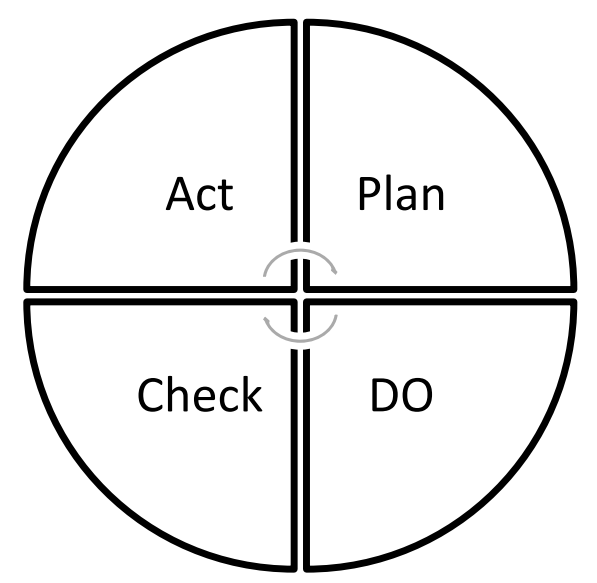

Untuk mengatasi permasalahan dana yang menjadi masalah dalam meningkatkan mutu MTs Sunan Kalijogo setelah di evaluasi kembali penggunaan dana untuk memenuhi kebutuhan sekolah dengan tepat, bila diseimbangkan dengan konsep Plan, Do, Check and Act dapat diperoleh susunan yang menjadi gambaran konsep PDCA dikemukakan oleh diantaranya sebagai berikut:

I. Plan (Pelaksanaan Rencana)

Pada dasarnya pelaksanaan segala sesuatu kegiatan diawali dengan perancanaan. Biasanya untuk merencanakan segala sesuatu memiliki jangka waktu, ada yang hanya sebentar ada pula yang memakan waktu cukup lama, berbeda-beda sesuai dengan perencanaan apa yang dilakukan. Tahap perencanaan ini harus mencakup: Memperjelas permasalahan, dimana asal dari masalah harus yang benar-benar ada dengan tujuan dapat sesuai dengan fakta yang sedang terjadi. Permasalahan yang diangkat disini mencankup pendanaan yang harus di ketahui dimana pembiayaan belum adanya RKA yang tepat guna. Kemudian target harus berkaitan dengan masalah dan cara mengatasi nantinya.

2. Do (Eksekusi) 
Dalam melaksanakan eksekusi dari perencanaan yang telah dilakukan maka dilakukan trial, hal ini memiliki tujuan untuk mengetahui tingkat keberhasilan maupun kegagalan yang akn dihadapi nantinya. Eksekusi pada pendanaan MTs Sunan Kalijogo ini berkaitan dengan perencanaan dari jalan keluar permasalahan pendanaan dari sekolah.

3. Check (Pengecekan)

Kegiatan ini dilakukan untuk memastikan kegiatan Do atau eksekusi dari solusi perbaikan berjalan dengan baik atau tidak sehingga dapat dilakukan kontrol dalam pemecahan masalah dari pendaaan MTs Sunan Kalijogo. Kegiatan control seta perbaikan dapat dilakukan secara berkelanjutan jika didapatkan ada permaslahan dari solusi yang sudah dilakukan.

4. Act (Penyesuaian)

Tahap ini bukan merupakan tahap akhir, dikarenakan siklus PDCA adalah lingkaran atau siklus penyelesaiaan masalah yang berulang-ulang dan bisa dikatakan tidak akan putus atau selesai, sehingga siklus tersebut dikatakan perbaikan secara berkesinambungan (continous improvement). Dalam tahap penyesuaian menemukan bahwa solusi yang berkaitan dengan pendanaan di MTs Sunan Kalijogo yang telah putuskan apakah sesuai serta memiliki resiko pada pembetulan dan hal yang di kerjakan adalah menentukan stadart yang harus dipenuhi baik secara mengoprasionalkan kinerja ataupun tindakan dari memperbaiki.

\section{KESIMPULAN}

Upaya peningkatan kualitas dari sekolah dalam pemenuhan dana maka dibutuhkan adanya penerapan sebuah pendekatan TQM. Prinsip manajemen keuangan pendidikan diantaranya: (I) keadilan yaitu dalam mengelola keuangan harus adil dan seimbang serta optimal; (2) efisiensi yang dilakukan baik efisiensi secara internal dan efisensi secara eksternal; (3) efektif menjadi sebuah patokan keberhasilan dalam mencapai tujuan sekolah dalam meningkatkan mutu sekolah; (4) transparansi terhadap berapa jumlah keuangan, berapa besar rincian penggunaan keuangan; dan (5) Akuntabel.

Penelitian yang dilakukan merupakan penelitian kualitatif. MTs Sunan Kalijogo ditemukan beberapa permasalahan yang menjadi sorotan yaitu belum baiknya standar pembiayaan di MTs Sunan Kalijogo. Pengimplementasian Total Quality Management (TQM) dengan konsep Plan, Do, Check, and Act (PDCA) MTs Sunan Kalijogo secara tidak langsung sudah dilaksanakan, tetapi dalam pelaksanaanya belum menunjukan keberhasilan yang signifikan. Permasalahan dana yang menjadi masalah dalam meningkatkan mutu MTs Sunan Kalijogo setelah di evaluasi kembali penggunaan dana untuk memenuhi kebutuhan sekolah dengan tepat, bila diseimbangkan dengan konsep Plan, Do, Check and Act.

\section{DAFTAR RUJUKAN}

Alkurnia, R, dan Anggriani, A. 2017. Pengelolaan MAnajemen Keuangan pada Lembaga Pendidikan (Studi pada sekolah Al-Islam dan Muhammadiyah di Surakarta). Universitas Sebelas Maret.

Alkaz, M. 2013. Makalah Manajemen Keuangan. (Online) (http://moozaalkaz.blogspot.com/20l3/0I/makalah-manajemen-keuangan-pendidikan.html), diakses 3 april 2019.

Masditou. 2017. Manajemen Pembiayaan Pendidikan Menuju Pendidikan yang Bermutu. Jurnal ANSIRU PAI, I (2).

Nur, M., Harun, Z.C., Ibrahim, S. 2016. Manajemen Sekolah dalam meningkatkan Mutu Pendidikan pada SDN Dayah Guci Kabupaten Pidie. Jurnal Administrasi Pendidikan, 4(I).

Peraturan Pemerintah Republik Indonesia Nomor 48 Tahun 2008 tentang Pendanaan Pendidikan pasal I ayat 3

Peraturan Pemerintah Republik Indonesia Nomor 48 Tahun 2008 tentang Pendanaan Pendidikan pasal 2 ayat I 
Peraturan Pemerintah Nomor 48 Tahun 2008 pasal 59

Undang-Undang Nomor 20 Tahun 2003 tentang Sistem Pendidikan Nasional Pasal 49 Ayat I

Sutarto. 20I5. Manajemen Mutu Terpadu (MMT-TQM) Teori dan Penerapan di Lembaga Pendidikan. UNY Press: Yogyakarta. 